\title{
International Standards for Development of Legislation Against hate Crimes and Article 282 Incitement of Hatred and Enmity, as well as Humiliation of Human Dignity of the Criminal Code of the Russian Federation
}

\author{
Sergey I. Bushmin* \\ Siberian Federal University \\ 79 Svobodny, Krasnoyarsk, 660041, Russia
}

Received 10.05.2017, received in revised form 18.06.2017, accepted 14.07.2017

\begin{abstract}
The conformity of the Russian criminal law, including Art. 282 Incitement of Hatred and Enmity, as well as Humiliation of Human Dignity of the Criminal Code of Russian Federation, to the norms of international law has always been under the close scrutiny not only of the scientific community, but also of the European Court of Human Rights. The formulation of the disposition of this article was admonished in the scientific literature and was criticized for the uncertainty of its content, which violates the freedom of expression and other constitutional rights.

This publication makes comparison of the disposition of the criminal law norm on the incitement of hatred and enmity, as well as the humiliation of human dignity, in the Russian criminal code and the recommendations for the development of legislation against hate crimes prepared by experts of the UN Human Rights Council and the OSCE Office for Democratic Institutions and Human Rights.

As a result of analysis of the provisions reflecting international standards for the development of legislation of this kind, objective and subjective elements of corpus delicti under Art. 282 of the Criminal Code of the Russian Federation, the paper gives the author's assessment of the degree of implementation of the recommendations of the UN and European Union experts in the criminal law of the Russian Federation. It also suggests that the construction features of the considered norm of the Criminal Code of the Russian Federation are not defects of lawmaking, but are generated by the action of permissible factors: the level of the social and economic development of the Russian Federation, the tradition of legal technique, the continuity of the provisions of the criminal law.
\end{abstract}

Keywords: the United Nations Convention on the Elimination of All Forms of Racial Discrimination, Practical guidance of the OSCE Office for Democratic Institutions and Human Rights, the Rabat Plan of Action on the prohibition of advocacy of national, racial or religious hatred that constitutes incitement to discrimination, hostility or violence, legislation against hate crimes; the incitement of hatred or enmity, protected features, social groups, victim identity.

This research is financially supported by the Russian Foundation for Basic Research and the Krasnoyarsk Regional Science and Technology Support Fund within the project A Comment to Criminal Legislation on Counteracting Terrorist and Extremist Activities (No. 16-13-24001).

DOI: 10.17516/1997-1370-0023.

Research area: criminal law and criminology, criminally-executive law.

(C) Siberian Federal University. All rights reserved

* Corresponding author E-mail address: star bush@mail.ru 


\section{Introduction to the research problem}

The States Parties in Art. 4 of the United Nations Convention on the Elimination of All Forms of Racial Discrimination declared any dissemination of ideas based on racial superiority or hatred, all incitement to racial discrimination, as well as all acts of violence or incitement to such acts directed against any race or group of persons of another color or ethnic origin, as well as the provision of any assistance for conducting racist activities, including its funding, as a punishable crime (Mezhdunarodnaia konventsiia...). On October 5, 2012, the so-called Rabat Action Plan, approved by the UN Human Rights Council in April 2013, which was the advisory document interpreting international legal norms, was adopted to draft national legislation to ensure the balance of freedom of expression and restriction of hate speech (Rabatskii plan deistvii...).

The Council of Europe did not adopt special conventions on crimes of inciting hatred and hate speech. All the efforts of the Parliamentary Assembly of the Council of Europe and the Council of Foreign Ministers of the Conference on Security and Cooperation in Europe (hereinafter OSCE) were aimed at developing recommendations for the unification of criminal legislation in this part in order to ensure the necessary balance between freedom, equality, public safety and legal regulation of hate, hate inciting and hate speech crimes. At a meeting of the OSCE Ministerial Council held in Maastricht in December 2003, the OSCE States Parties recognized the danger posed by hate crimes and committed themselves to combating them. The OSCE Permanent Council adopted a decision authorizing the Office for Democratic Institutions and Human Rights of this organization (hereinafter ODIHR) to work on the problem of hate crimes (Reshenie Postoyannogo soveta...). In 2009, ODIHR prepared practical recommendations reflecting strategic issues in the development of laws against hate crimes (Zakonodatel'stvo protiv prestuplenij...). However, these recommendations diverge in separate paragraphs with the provisions of the Rabat Action Plan.

\section{Statement of the problem}

In domestic scientific publications the question of formulation of the disposition of Art. 282 Incitement of Hatred and Enmity, as well as Humiliation of Human Dignity of the Criminal Code of the Russian Federation was often criticized (see, for example, Minochkina, 2016; Matskevich, 2014; Sergun, 2013). Besides, the applicants in the complaints sent to the Constitutional Court of the Russian Federation paid attention to the uncertainty of its content, which violates freedom of expression or other constitutional rights (Opredelenie Konstitutsionnogo Suda...). We believe that the text of the current provision of the Criminal Code of the Russian Federation on criminal responsibility for inciting hatred and enmity, as well as humiliation of human dignity, is the result of the synthesis of the main recommendations of OSCE/ODIHR on the development of laws against hate crimes and certain distinct provisions of the Rabat Plan.

\section{Discussion}

ODIHR believes that a well-functioning law against hate crimes should indicate such signs of a victim that are obvious or well known to the perpetrator. In addition, to ensure that the scope of the laws against hate crimes is broad enough, they should use a combination of terms such as "race", ethnicity, national origin and nationality (Zakonodatel'stvo protiv..., 2009: 71).

The Russian legislator uses a set of criteria "gender, race, nationality, language, origin, attitude to religion" as protected features that unite a group of persons in the disposition of 
Art. 282 of the Criminal Code of the Russian Federation, taken in part from the above Art. 1 of the Convention on the Elimination of All Forms of Racial Discrimination (Mezhdunarodnaia konventsiia...), and in part from Part Ii of Art. 20 of the International Covenant on Civil and Political Rights, where they are listed as haters, "Any statement in favor of national, racial or religious hatred that constitutes incitement to discrimination, hostility or violence must be prohibited by law" (Mezhdunarodnyi pakt...).

The OSCE recommendations contain a warning for lawmakers that some of the signs create confusion. In particular, where the term "social group" is used without a clear definition, there is a danger that the law may not achieve its goals. But at the same time ODIHR clarifies that there are no universal criteria for the choice of protected features, it is necessary to take into account factors such as historical conditions, current social problems and the prevalence of specific types of crimes (Zakonodatel'stvo protiv..., 2009: 56). It follows from this formulation that the practical leadership of ODIHR does not establish an absolute prohibition on the use of the "social group" in the description of hate crimes, but the formalization of this protective feature should be a primary task in improving the norm of Russian criminal law on responsibility for inciting hatred and enmity, as well as the humiliation of human dignity.

In the content of the following recommendation, the opinions of European experts and UN experts differed. Thus, the ODIHR working group concluded that the laws against hate crimes should not provide for the mandatory presence of any particular emotional state, such as "hatred" or "enmity", in a criminal as a motive. Their use can lead to incorrect interpretation of the norm. For this reason, the term "prejudice" is used in the guide predominantly instead of the term "hatred", which has a broader meaning, which is confirmed only by the presence of some form of bias against any personal sign of the victim (Zakonodatel'stvo protiv..., 2009: 21).

On the contrary, the Rabat Action Plan asserts that the wording of the law should not shy away from the formulation of international law, including Art. 20 of the International Covenant on Civil and Political Rights, in particular, this means that it is not necessary to replace "hard" terms like "hatred" with softer synonyms (Verkhovsky, 2014: 33).

The Russian legislator took the position of the UN Human Rights Council. The objective side of the offense under Art. 282 of the Criminal Code of the Russian Federation (as amended by Federal Law No. 22 of 07.07.2003), contained the wording of three alternative acts: actions aimed at incitement of national, racial or religious hatred, humiliation of national dignity, as well as propaganda of exclusivity, superiority or inferiority of citizens by the sign of their relation to religion, nationality or race. Bearing in mind the 1997 recommendations of the Committee of Ministers of the Council of Europe that the term "incitement of hatred" is interpreted as a concept that covers all forms of expression that include the proliferation, provocation, promotion or justification of racial hatred, xenophobia, anti-Semitism or other forms of hatred based on intolerance, including intolerance in the form of aggressive nationalism or ethnocentrism, discrimination and hostility towards minorities, migrants and persons with emigrant roots (Zakonodatel'stvo protiv..., 2009), the Federal Law No. 162-FZ of 08.12.2003 amended the Art. 282 of the Criminal Code of the Russian Federation, which is currently in force. Due to the addition to the disposition of the norm of the sign "inciting hatred", the third act, which became superfluous after the changes in the criminal law, was excluded. 
The individual ODIHR recommendations are implemented through the use of other provisions of domestic criminal law, including the provisions of the General Part of the Criminal Code of the Russian Federation. The fact that laws against hate crimes should be applied and the cases where the offender is mistaken about the identity of the victim is realized in the territory of the Russian Federation in accordance with the theory of guilt and the application of the rules of the criminal-legal assessment of the act as an attempt on the crime in establishing the factual error of the person, committing a crime. The ODIHR OSCE Practical Guide lists cases that required such a legislative proposal. Thus, after the attacks of September 11, 2001, a wave of crimes of "retaliation" against Muslims swept across the United States. Their victims were Sikhs, Hindus and people of Hispanic origin, whom the attackers took for Muslims. Such crimes, related to mistakes in the perception of identity, also took place in London after a series of bombings on July 7, 2005.

However, the ODIHR guide is instructed to ensure that there is the protection of people who are associated with individuals or groups that have protected characteristics, or belong to such groups, in laws against hate crimes. In the United States, there was a documented trend of crimes directed against interracial couples and families. Similarly, a study in Finland showed that onefifth of hate crimes were committed against ethnic Finns who were "in the company of a person of foreign origin" or whose "spouse was a person of foreign origin". This recommendation should be of undoubted interest for the legislative activity of the Russian legislator in the direction of bringing Art. 282 of the Criminal Code of the Russian Federation in line with international standards.

\section{Conclusion}

The presented analysis of the text of Art. 282 of the Criminal Code of the Russian Federation, the recommendations of the UN Human Rights Council and the ODIHR OSCE Practical Guide demonstrates a general compliance of the considered norm of the Russian criminal law with the strategic provisions for the legislative formulation of the criminal prohibition of hate crimes. The features of designing the composition of criminal incitement of hatred and enmity, as well as humiliation of human dignity, are in the generally accepted framework that determine the specificity of national legislation, depending on the level of socio-economic development of the Russian Federation, the traditions of legal technique, the historical continuity of the provisions of the criminal law.

In assessing the feasibility of the international recommendations on legislation on hate crimes in Art. 282 of the Criminal Code of the Russian Federation, one should take into account that the most comprehensive and consistent law will not allow achieving the set goals unless it is also applied in the spirit and sense of international legal instruments, what the fundamental recommendations of international experts are also based on.

\section{References}

Mezhdunarodnaia konventsiia o likvidatsii vsekh form rasovoi diskriminatsii [International Convention on the Elimination of All Forms of Racial Discrimination]. Available at: http://www. un.org/ru/documents/decl_conv/conventions/raceconv.shtml

Mezhdunarodnyi pakt o grazhdanskikh i politicheskikh pravakh [International Covenant on Civil and Political Rights]. Available at: http://www.un.org/russian/documen/convents/pactpol.htm 
Mezhdunarodnye rekomendatsii po primeneniiu zakonodatel'stva protiv prestuplenii na pochve nenavisti $i$ ikh realizatsiia sudami $R F$ ne rassmatrivaiutsya $v$ ramkakh nastoiashchei publikatsii [International recommendations on the application of legislation against hate crimes and their implementation by Russian courts are not considered in the context of this publication].

Opredelenie Konstitutsionnogo Suda RF ot 19 fevralia 2009 g. № 154-O-O «Ob otkaze v priniatii $\mathrm{k}$ rassmotreniiu zhaloby grazhdanina Chulkina Viktora Aleksandrovicha na narushenie ego konstitutsionnykh prav stat'ei 282 Ugolovnogo kodeksa Rossiiskoi Federatsii» [Definition of the Constitutional Court of the Russian Federation of February 19, 2009. No. 154-O-O “On Refusal to Accept the Complaint of Citizen Viktor Chulkin for the Violation of His Constitutional Rights under Article 282 of the Criminal Code of the Russian Federation"], In SPS «Konsul'tantPlius» [Computer-based legal research system ConsultantPlus]; Opredelenie Konstitutsionnogo Suda RF ot 22 aprelia 2010 g. № 564$\mathrm{O}-\mathrm{O}$ «Ob otkaze v priniatii k rassmotreniiu zhaloby grazhdanina Zamuraeva Romana Vladimirovicha na narushenie ego konstitutsionnykh prav polozheniem chasti pervoi stat'i 282 Ugolovnogo kodeksa Rossiiskoi Federatsii» [Definition of the Constitutional Court of the Russian Federation of April 22, 2010 No. 564-O-O "On Refusal to Accept the Complaint of Citizen Roman Zamuraev for the Violation of His Constitutional Rights under the provision of Part I of Article 282 of the Criminal Code of the Russian Federation”], In SPS «Konsul'tantPlius» [Computer-based legal research system ConsultantPlus].

Rabatskii plan deistvii po zapreshcheniiu propagandy natsional'noi, rasovoi ili religioznoi nenavisti, predstavliaiushchei soboipodstrekatel'stvo kdiskriminatsii, vrazhde ili nasiliiu (neofitsial'nyi perevod) [The Rabat Action Plan to Prohibit the Propagation of National, Racial or Religious Hatred, which Includes Incitement to Discrimination, Hostility or Violence (unofficial translation)]. Tsentr Sova. Available at: http://www.sova-center.ru/racism-xenophobia/publications/2014/11/d30593// (accessed 6 November 2014).

Recommendation No. $R$ (97) 20. Of the Committee of Ministers to member states on "Hate Speech”. Available at: https://rm.coe.int/1680505d5b

Reshenie Postoyannogo soveta OBSE № 621 «Tolerantnost' i bor'ba s rasizmom, ksenofobiei $i$ diskriminatsiei» [Solution of the OSCE Permanent Council No. 621 Tolerance and the Fight against Racism, Xenophobia and Discrimination]. Available at: http://www.osce.org/documents/ pc/2004/07/3374_en.pdf.

See, for example, Minochkina, Ia. (2016). Iazyk vrazhdy - otkryvaia iashchik Pandory [The language of enmity - opening the Pandora's box], In Pretsedenty Evropeiskogo suda po pravam cheloveka [Precedents of the European Court of Human Rights], 10; Matskevich, I.M. (2014). O predlozheniiakh, napravlennykh na dal'neishee sovershenstvovanie zakonodatel'stva ob ekstremizme [On proposals aimed at further improving the legislation on extremism], In Iuridicheskoe obrazovanie i nauka, Konsul'tantPlius [Legal Education and Science, ConsultantPlus], 2; Sergun, E.P. (2013). Kriminalizatsiia propagandy ekstremistskoi ideologii kak otlichitel'naia osobennost' novoi ugolovno-pravovoi politiki $\mathrm{v}$ sfere obespecheniia konstitutsionnoi bezopasnosti Rossii [Criminalization of the propaganda of extremist ideology as a distinctive feature of the new criminal law policy in the sphere of ensuring the constitutional security of Russia], In Vestnik Saratovskoi gosudarstvennoi iuridicheskoi akademii [Bulletin of Saratov State Law Academy], 1 (90), 138.

Verkhovsky, A. (2014). Ugolovnoe pravo OBSE protiv prestuplenii nenavisti, vozbuzhdeniia nenavisti i iazyka vrazhdy [Criminal law of OSCE against hate crimes, incitement of hatred and hate speech]. Moscow, Tsentr Sova, $280 \mathrm{p}$. 
Zakonodatel'stvo protiv prestuplenij na pochvenenavisti: prakticheskoe rukovodstvo [Legislation against hate crimes: practical guidance] (2009). Warsaw, Poligrafus Andrzej Adamiak, 82 p.

\title{
Международные стандарты разработки законодательства против преступлений на почве ненависти \\ и ст. 282 УК РФ «Возбуждение ненависти и вражды, а равно унижение человеческого достоинства»
}

\author{
С.И. Бушмин \\ Сибирский федеральный университет \\ Россия, 660041, Красноярск, пр. Свободный, 79
}

\begin{abstract}
Соответствие российского уголовного закона, в том числе ст. 282 УК РФ «Возбуждение ненависти и вражды, а равно унижение человеческого достоинства», нормам международного права всегда было под пристальным вниманием не только научной общественности, но и Европейского суда по правам человека. Формулировка диспозиции этой статьи подвергалась замечаниям в научной литературе и вызывала критику в части неопределенности ее содержания, нарушающего свободу выражения мнений и иные конституционные права.

В настоящей публикачии проведено сопоставление диспозиции уголовно-правовой нормь российского уголовного закона о возбуждении ненависти и вражды, а равно унижении человеческого достоинства, и рекомендаций по разработке законодательства против преступлений на почве ненависти, подготовленных экспертами Совета по правам человека ООН и Бюро по демократическим институтам и правам человека ОБСЕ.

В результате анализа положений, отражающих международные стандарты разработки законодательства такого рода, объективных и субъективных признаков состава преступления, предусмотренного ст. 282 УК РФ, дана авторская оценка степени реализации в уголовном законе РФ рекомендаций специалистов ООН и Европейского союза, высказано суждение о том, что особенности конструирования рассматриваемой нормы УК РФ не являются дефектами правотворчества, а порождены действием допустимых факторов: уровнем соииально-экономического развития РФ, традицией юридической техники, преемственностью положений уголовного закона.
\end{abstract}

Ключевые слова: Конвенция ООН о ликвидации всех форм расовой дискриминации, практическое руководство Бюро по демократическим институтам и правам человека ОБСЕ, Рабатский план действий по запрещению пропаганды национальной, расовой или религиозной ненависти, представляющей собой подстрекательство к дискриминации, вражде или насилию, законодательство против преступлений на почве ненависти, возбуждение ненависти или вражды, защищаемые признаки, сочиальные группь, идентичность жертвы.

Исследование финансируется Российским фондом фундаментальных исследований и Красноярским региональным фондом поддержки науки и техники в рамках проекта «Комментарий к уголовному законодательству о противодействии террористической и экстремистской деятельности» (№ 16-13-24001).

Научная специальность: 12.00.08 - уголовное право и криминология, уголовно-исполнительное право. 